\title{
Physical Place and Cyberplace: The Rise of Personalized Networking*
}

\author{
BARRY WELLMAN
}

\section{A computer network is a social network}

\section{The network revolution}

We find community in networks, not groups. Although people often view the world in terms of groups (Freeman, 1992), they function in networks. In networked societies: boundaries are permeable, interactions are with diverse others, connections switch between multiple networks, and hierarchies can be flatter and recursive. The change from groups to networks can be seen at many levels. Trading and political blocs have lost their monolithic character in the world system. Organizations form complex networks of alliance and exchange rather than cartels, and workers report to multiple peers and superiors. Management by multiply-connected network is replacing management by hierarchal tree and management by two-dimensional matrix (Berkowitz, 1982; Wellman, 1988; Castells, 1996). Communities are far-flung, loosely-bounded, sparsely-knit and fragmentary. Most people operate in multiple, thinly-connected, partial communities as they deal with networks of kin, neighbours, friends, workmates and organizational ties. Rather than fitting into the same group as those around them, each person has his/her own 'personal community' (Wellman and Leighton, 1979; Wellman, 1999a).

Theorists and researchers have been arguing the networked, individuating nature of the contemporary condition. Eric Wright (1979) has taught us that social class is a relational phenomenon: control over one's own labour power and that of others. Manuel Castells (1972) has taught us that class pertains to relations of production and reproduction including communities. Anthony Giddens (1991) has incorporated space-time decoupling into his depiction of 'later modernism'. Ulrich Beck (1996), like Giddens and Parsons (1943), has argued that modern society is in a condition of individualism. More concretely,

\footnotetext{
* My thanks to Bev Wellman who identified 'Place-to-Place' and helped me think it through as we drove down the Sepulveda Pass on the 405, mobile phone clipped to my belt. I've also benefited from cyber- and meatspace conversations with Andrew Beveridge, Jeffrey Boase, Erin Bradner, Sarah Busse, Wen-Hong Chen, Mark Chignell, Sabrina Cutaia, Dimitrina Dimitrova, Glenn Grube, Keith Hampton, Caroline Haythornthwaite, Emmanuel Koku, Jerry Krase, Kristine Klement, Lyn Lofland, William Michelson, Michael Milton, Nancy Nazer, Andrew Odlyzko, Bandana Purkayastha, Anabel Quan Haase, Detelina Radoeva, Karen Ramsay, Mary Rees-Nishio, Howard Rheingold, Charles Tilly, Chris Toulouse, Gerda Wekerle, Beverly Wellman, James Witte, Alesia Zuccala, Sharon Zukin, and the correspondents at the American Sociological Association's Community and Urban Sociology email discussion list who commented on a preliminary minidraft (see www.commurb.org/features/futurecommunity.shtml). My compatriots at the University of Toronto's NetLab, Centre for Urban and Community Studies, Knowledge Media Design Institute and the Bell University Laboratories have created stimulating milieus for thinking about cyber-society. The research that underlies this paper has been supported by the Bell University Laboratories, the Social Science and Humanities Research Council of Canada, and the Office of Learning Technologies (Human Resources and Development Canada).
} 
time geographers such as Torsten Hägerstrand have documented how time and space constrain people's lives (Carlstein et al., 1978).

These arguments and evidence converge in thinking about the transformation of community from solidary groups to individualized networks. The structure and composition of community networks affect people's control over their lives, and people's structural positions in community networks affect the kinds of resources to which they have access. The proliferation of personal community networks happened well before the development of cyberspace (Wellman and Wetherell, 1996; Wellman, 1999a). Yet the rapid emergence of computer-mediated communications means that relations in cyberplaces are joining with relations on the ground.

Complex social networks have always existed, but recent technological developments in communication have afforded their emergence as a dominant form of social organization. When computer-mediated communication networks link people, institutions and knowledge, they are computer-supported social networks. The technological development of computer networks and the societal flourishing of social networks are now in a positive feedback loop. Just as the flexibility of less-bounded, spatially dispersed social networks creates demand for the world wide web and collaborative communication, the breathless development of computer networks nourishes societal transitions from little boxes to social networks.

My principal concerns in this article are:

- How networks of community exist in physical places — such as neighbourhoods and cyberplaces - like the Internet;

- How the development of computer-supported community networks affects access to resources.

I define 'community' as networks of interpersonal ties that provide sociability, support, information, a sense of belonging and social identity. I do not limit my thinking about community to neighbourhoods and villages. ${ }^{1}$ This is good advice for any epoch and especially pertinent for the twenty-first century.

Developments in computer-mediated communication are currently exciting the public, scholars, financiers, the media and politicians. Yet it is when technological changes become pervasive, familiar and boring that they affect societies the most. This is an old story. Few scholars think about the telephone now (but see Fischer, 1992), yet it has thoroughly affected the spatial and social structure of communities. I do not argue technological determinism (e.g. Ogburn, 1950), for people and institutions take over and reorient technological developments. Rather, I examine the 'social affordances' of technology: the possibilities that technological changes afford for social relations and social structure. ${ }^{2}$

1 George Hillery showed a generation ago (1955) that sociology has and needs multiple definitions of community. Contemporary community sociologists have two main foci (Wellman, 2000b): (1) the ecological juxtaposition of people in the same locale; (2) interpersonal relations (as defined above), no matter where they are located. Although my own work has focused on the interpersonal definition of community, I have always believed that community can be sought in neighbourhoods - and sometimes even found there (Wellman, 1979; 1999a; Wellman and Leighton, 1979). Yet it would be myopic to confine our search for community to neighbourhoods. Although not every network is a community unless you think of NATO or interlocking corporate structures as communities - every interpersonal community is a network. Whether such communities are found in - or confined to - neighbourhoods is a secondary question. Other usages of 'community' are common: (3) Internet marketers label as a 'community' disconnected aggregations of random visitors to websites (see also Henshall, 2000); 'Talk City', a commercial set of websites oriented to American women, has a 'Vice-President, Community', whose job it is to encourage women to chat, eyeball ads and buy things (www.talkcity.com); (4) businesses talk about 'communities of practice' (Wenger, 1998): colleagues sharing lore either within or between organizations.

2 'Affordances' is a term widely used in the study of human-computer interaction (Norman, 1999). Erin Bradner (2000), writing for computer scientists, has coined the term 'social affordances' to emphasize the 
I focus on how affordances in computer-supported interpersonal communication affect the ways in which people connect with each other: greater bandwidth for non-faceto-face communication; wireless portability of computerized communication devices; globalized ease of connecting with others and accessing information; and the personalization of technology and knowledge management (discussed in more detail in Wellman, 2000a). I assume that those that have a clear technological development path and likely economic rationale will continue to take root and proliferate. The human use of these technologies is creating and sustaining community ties. These ties have transformed cyberspace into cyberplaces, as people connect online with kindred spirits, engage in supportive and sociable relationships with them, and imbue their activity online with meaning, belonging and identity.

When sociologists think about the future, they often focus on interpersonal abuses to be redressed and structural wrongs to be righted (see the Utopian statements in Risman et al., 2000). By contrast, I examine the opportunities and transformations afforded by computerized communication networks. To be sure, these technologies also have negative affordances, such as interpersonal alienation, lessened privacy, increased surveillance and machine-dependent vulnerability to computerized crime and breakdown (forecast a century ago by E.M. Forster, 1909). But to address these other issues would take many more pages.

\section{The social affordances of computerized communication networks}

Broader bandwidth The number of bits that can be pushed through a computer network connection in a given hour has risen from 110 bits per second in the mid-1970s to routine home speeds ranging from 30,000bps (with dial-up telephone modems) to 1 million (M) bps (for cable modems and ADSL phone connections). It will soon rise sharply again. High capacity bandwidth is important for its speed, so that text messages and web pages become readable without distracting delay. It affords instant messaging and feedback. It also affords the exchange of complex communication, so that large documents, drawings etc. can be attached to email messages or read on web pages. Bandwidth affords the transmission of high-quality pictures, fostering 'telepresence' (Buxton, 1992). One new application connects a digital picture frame to a website (www.ceiva.com) so that grandparents can see updated pictures of their grandchildren. Another transmits continuous video from a 'fly-on-the-wall' camera for parents to keep a concerned eye on frail elderly grandparents (www.camrades.com).

Although the selling point of current $1 \mathrm{Mbps}$ home broadband connections is their speed/bandwidth, our 'Netville' study of a leading-edge wired suburb (with 10Mbps connections) finds that the always-available feature is more valued than sheer speed (Hampton and Wellman, 2000; Hampton, 2001). As high-speed connections do not block telephone calls from the family phone and cost no more for being online ' $24 \times 7$ ', people get in the habit of sending email or web-surfing whenever the thought strikes them, glancing frequently at the incoming email box, or frequently checking to see who is currently available for instant messaging, that is, email that happens in real time rather than through one-way sending and receiving (Issacs, 2000). The easily-available Internet — no need to boot up or connect - makes the web a convenient place to find quick information and makes email a handy way to share quick thoughts. It also makes it easier to work from home. Just as employers complain about workers' use of the Internet for personal matters, family members complain that their loved ones are tied to their computers during their supposed leisure hours (Shapiro, 1998; Nie and Erbring, 2000).

social as well as individual implications of the technological features of computer-supported communication networks and human-computer interfaces (see also Gaver, 1996). 
Wireless portability $\mathrm{We}$ are moving to a world of both ubiquitous and portable computing. Ubiquity means the widespread availability of usable computing and computer-mediated communication. Portability means that you can take it with you: you do not have to be dependent on others' equipment to connect to the Internet. By the end of 2001, there will be more wireless, mobile cellphones than wired phones in use worldwide, according to Kurt Hellstrom, the president of cellphone maker Ericsson (Ripley, 2001). Although wires still carry the most bandwidth, mobile phones will soon be integrated with the multifunctional capacity of computers. Pedestrians, those in cars and airline passengers will have wireless connectivity with the Internet, enabling Internet, voice (and possibly video) access anywhere and web-browsing on the go (Randall, 2001). Favourite radio and television broadcasts will be available worldwide, be they BBC chatter, MoTown sounds or hyper-specialized narrowcasters to small communities of shared interest (Howard, 2000; Markets, 2000). Projections suggest that well before the end of the decade, there will be more wireless subscribers with Internet access capabilities than wired subscribers. ${ }^{3}$

The proliferation of portability will be both the embracing of — and the negation of - ubiquitous globalization. Computer-supported communication will be everywhere, but because it is independent of place, it will be situated nowhere. The importance of a communication site as a meaningful place will diminish even more. The person - not the place, household or workgroup - will become even more of an autonomous communication node. Contextual sense and lateral awareness will diminish. If people can listen to favourite radio stations wherever they are, they become less aware of the importance of gospel music to southern Americans, farm news to midwesterners, and hiphop to northeastern city dwellers.

Globalized connectivity The world of computerization has oscillated between centralized control - computer centres — and personal control — standalone computers (Kling and Iacono, 1984). The current situation, 'networked computing', means that information (and control) flow up and down between central servers and somewhat autonomous personal computers. Despite organizational control, most people in organizations also use their computers for social, community-maintaining reasons (Haythornthwaite and Wellman, 1998). Computer networks are expanding as the worldwide web is becoming more comprehensive and worthy of its name. The 'digital divide' - the income/ locational/cultural gap between those comfortable with computerization and those not is shrinking within the western world; the gender gap has already disappeared (NTIA, 1999; Reddick et al., 2000; Fong, et al., 2001; Haythornthwaite and Wellman, 2001). The Napster music-sharing program is just a foretaste of peer-to-peer network among computers and their masters (Alwang, 2001).

Global portability will be afforded by the standardization of mobile phone specifications, the development of standards (such as Bluetooth, 802.11b and HomeRF) for ad hoc communication between changing sets of partners, the spread of wireless towers to physically isolated and impoverished 'fourth world' areas (Castells, 1998; OnSat, 2000) and the availability of satellite communication in remote areas. Bedouin tribespeople in Qatar already chat on cellphones while herding sheep and use satellite dishes to participate in TV talk shows (Weaver, 2000). The development of globalized portability will mean the potential availability of 'small world' interpersonal connectivity. All will be connected to all, either directly or through short chains of indirect ties.

3 PC Magazine (2000), summarizing a proprietary IDC report. Although slow transmission rates, poor web design and small screen sizes will initially limit wireless use, there are clear development paths, economic drivers and social desires to overcome these problems. 
Personalization The Internet has changed the nature of the continuing tension between centralization and personalization. The Internet's original prime use, email, has been a personal medium, with individuals usually managing their own address books and sending messages one-to-one. By contrast, the web affords both personalization and centralization. Although choice of sites viewed is usually a personal decision, the response of the sites have been standardized at all but the most superficial level. Yet personalization tools are developing. People should soon be able to tell their communications devices whom they wish to get messages from, about what and when. They should soon be able to provide personalized responses on voicemail and email to specific individuals. Website portals such as www.excite.com are becoming more tailorable to individual preferences so that individualized news compilations are available, at the cost of reducing the populace's common awareness of current events. Personal software agents can scan online newsgroups and chat groups, collecting and organizing desired information.

Personalization is not necessarily the same as portability. With portable computing, you take your communications device with you. By contrast, ubiquitous computing could mean that whenever you log on to a communications device, it knows who you are, where you are and what your preferences are. Active badges, experimented with by Xerox and others, tell a central computer where in the building you are (Harper et al., 1992). Your messages follow you. This makes most networked devices smart; it also makes surveillance easier (Weiser, 1993; Buderi, 2001).

Thus, personalization need not mean individual isolation. Collaborative filtering is developing, where people contribute to evaluations of books, restaurants (Schiesel, 2000), politicians and movies (e.g. www.movielens.umn.edu/). People can use their filters and personal agents to find like-minded others and form communities of shared interest. Yenta is an experimental matchmaker system, designed to find people with similar interests and introduce them to each other online (Foner, 1997). Will they be physically available for face-to-face interactions? 'If you combine virtual community, collaborative filtering and web-to-cellphone, you get a scenario in which you always know who in your physical vicinity at the moment shares certain affinities and willingness to be contacted' (Howard Rheingold, personal email, 11 January 2000; see also Rheingold, 1993; 2000).

\section{Communities transcend the group and the locality}

The proliferation of computer-supported social networks is fostering changes in the ways that people contact, interact with and obtain resources from each other:

- One transition was the nineteenth/twentieth century move from door-to-door to place-to-place community relationships. This transition was driven by revolutionary developments in both transportation and communication. It was a move away from a solidary group in a single locale to contact between people in different places and multiple social networks. Households became important centres for networking; neighbourhoods became less important.

- Another transition has already started: the shift away from place-based interhousehold ties to individualized person-to-person interactions and specialized role-torole interactions.

\section{Door-to-door}

First, a brief excursion to the past to provide some grounding before travelling back to the future. All urban and community scholars 'know' that since the Agricultural Revolution, community has traditionally been based in itinerant bands, agrarian villages, trading towns and urban neighbourhoods. In these milieus, people walked to visit each other. The community was spatially compact and densely-knit (Barthélemy and Contamine, 1985; Thébert, 1985; Ward, 1999). If most settlements or neighbourhoods contained less than a 
thousand people, then almost everybody would know each other: even today we carry around with us a mental list of a thousand or so souls who we know well enough to converse with (Kochen, 1989).

Communities were bounded, so that most relationships happened within their gates rather than across them. Much intercourse stayed within neighbourhoods, even in big cities and trading towns. If wandering bands travelled to new fertile areas, they went together. Such communities had door-to-door connectivity. When people went to visit each other, they generally walked. If they were affluent and living in post-bridle/stirrup times, they travelled on horses, in carriages and on boats. Whatever the mode of transportation, only heavily veiled and wilfully myopic elites could avoid being steeped in local context - and if they were unlucky, avoid stepping in it. Social class was based on control over labour power and resources. It was based on position within the small community and the access to external resources afforded by the few links to outside.

This is an article about the future and not the past, so I will not belabour the details of preindustrial connectivity. Pastoralist nostalgia for quaint little villages leads to overlooking the evidence for preindustrial connectivity over long distances. Hunters, gatherers, soldiers, prostitutes, artisans, peddlers and shepherds travelled between towns, regions and continents. Elite traders, scholars and the idle rich journeyed to market towns, great universities and resorts. As Charles Tilly has pointed out, it is easy to project the near past onto the distant past and overestimate the prevalence of closed, immobile communities:

Of the million-odd years human beings have been around, a majority have lived in settled villages for no more than four millennia. Most of the time, humans have been hunters, gatherers, and/or flock-tending nomads. The yurt is a better logo for humanity than the stone cottage. Although culturally homogeneous localities have of course existed, such crucial structures as trade diasporas, religious solidarities, lineages, and mutual aid networks have commonly cut across localities. Because states and holders of capital were pushing in the same direction, the period from 1750 to 1950 was, contrary to myths of mobility, humanity's great time of settling into legally established settled communities. Fixed capital and circumscribing states promoted immobile labor forces (personal email, 11 February 2000).

Whether travelling with yurts or huddling in stone cottages, the important point is that people went through villages and neighbourhoods to communicate. Most people in a settlement knew each other, were limited by their footpower in terms of whom they could contact, and when they visited someone most neighbours knew who was going to see whom and what their interaction was about. The contact was essentially between households, with the sanction — or at least the awareness — of the settlement.

Such door-to-door communities contained triple inequalities. Not only did a community's inhabitants vary in the amounts of resources to which they had access, their communities and societies varied as well. The densely-knit interconnectivity of such communities made it easy to control material goods and behaviour. The tight boundaries that contained interactions ensured that few resources — including knowledge — would be imported or exported. The broadly-based ties of community members ensured that much feasible support could be provided, but only when the community wanted to provide it. As there was only one network, the only alternative was running away - to the military, the church or merchant traders (Wolf, 1966; Wellman and Leighton, 1979; Davis, 1983; Bodemann, 1988).

To be sure, place-independent communities have always existed, especially among the leisure class, professional travellers and hobos. The home-visiting elites in Jane Austen's novels were always galloping/carriaging to-and-fro. Yet place-independent communities needed technological help to become generally widespread. Until the nearly simultaneous proliferation of railroads and telegraphs in the mid-nineteenth century, communication speeds were about the same as door-to-door transportation speeds. The 
telegraph greatly increased the speed of communication. ${ }^{4}$ Since then, the effective speed of transportation has increased twofold from the $30-50 \mathrm{mph}$ of early railroad speed (Paullin, 1932) to 60mph for automobiles, fivefold to $150 \mathrm{mph}$ for high-speed trains, and sixtyfold to $600 \mathrm{mph}$ for airliners.

Although the telegraph was generally only used for short, high-priority messages, it was the harbinger of communication becoming divorced from transportation. The increased speed of routine communication has been more dramatic than the increased speed of transportation. Communication has broken loose from the need to be carried somewhere by someone. Now it is being conducted at the speed of light by electrons on wires and through the 'ether'. As long-distance telephone systems proliferated and became routinely affordable, the $30-50 \mathrm{mph}$ speed of mail carried on early trains has increased more than 50,000 times. A 20-page document might take 30+ hours to go 1,000 miles in 1850. It takes a few seconds now, with the limiting factor being the speed of personal connections to the Internet. ${ }^{5}$ This huge increase in speed has made door-to-door communications residual, and made most communications place-to-place or person-toperson. The length of the message is a more salient limiting factor than the distance that the message has to travel.

\section{Place-to-place}

Community goes beyond the neighbourhood When I was a child living in the Bronx, New York City, I took the subway several times a week to midtown Manhattan, going through the African-American Harlem area. I dared not think of getting off there. The express train did not even stop at its stations, as it sped middle-class Bronxites to the work and fun of Times Square and Greenwich Village. I got on the train in the Bronx, got off in midtown, and saw nothing in-between except other passengers. Forty years later I do the same thing when travelling transcontinentally. I get on an aeroplane in Toronto and get off five hours later in Los Angeles, with only the Rockies poking through the clouds to capture my attention to the passing scene. As on the subway, passengers rarely communicate with each other. Between visits, I telephone or, increasingly, I email. Friends send emails, asking me to look at pictures of their weddings and children on their websites.

The big change from door-to-door to place-to-place community is old news apparent to all but politicians and community scholars habituated to thinking of neighbourhoods as the only possible sources of community. If 'community' is defined socially and not spatially, it is clear that contemporary communities are rarely limited to neighbourhoods (Wellman and Leighton, 1979; Wellman, 1999a). This is because people usually obtain support, companionship, information and a sense of belonging from those who do not live within the same neighbourhood or even within the same metropolitan area. People maintain these community ties through phoning, writing, driving, railroading, transiting and flying. Although characteristics of neighbourhoods remain important - as differential real-estate values between neighbourhoods testify neighbourhoods are not important sources of community. They have become variably safe and salubrious milieus from which people sally forth in their cars, telephone from their kitchens or email from their dens.

Most North Americans have little interpersonal connection with their neighbourhood; they have even less connection to the social control of a neighbourhood group. ${ }^{6}$ Community interactions have moved inside the private home — where most entertaining,

4 In theory, telegrams travelled at the speed of light, although limitations caused by human operators and mechanical failure inevitably made the actual user-to-user speed appreciably slower.

5 I assume at each end: 33 kilobits/second effective speed of telephone 'dial-up' modems; this will rapidly increase to 10 megabits/second in this decade.

6 Nozawa (1997) and Otani (1999) show that only a minority of Japanese community ties are local, despite the many neighbourhood institutions to promote solidarity, support and social control. 
phone-calling and emailing takes place — and away from chatting with patrons in public spaces such as bars, street corners and coffee shops. Even when people do go out with others - to restaurants or movie theatres - they usually leave their neighbourhoods (Lofland, 1998). The percentage of Americans regularly socializing with neighbours has been steadily declining for at least 25 years. In 1999, only $20 \%$ spent a social evening with neighbours several times per week as compared with $30 \%$ in 1974. Similarly, regularly socializing in bars has declined from $11 \%$ to $8 \%$ (Smith, 1999).

Although I have concentrated on spatial effects here - community ties spreading beyond neighbourhoods - social structural effects are important too, especially the predominance of networks (rather than groups) in communities. ${ }^{7}$ Living in networks has profound implications for the nature of place-to-place communities as compared with door-to-door communities:

- The ability to connect with multiple social milieus, with limited involvement in each milieu.

- The decreased control over inhabitants' behaviour that each milieu has.

- The decreased commitment of each milieu to its inhabitants' well-being.

- People must actively maintain their sparsely-knit ties and fragmented networks. By contrast, it is easier for people in groups to sit back and let group dynamics and densely-knit structures do the work. That is why friendship networks are less apt than kinship networks to persist in times of overload.

- The ability to re-establish relationships quickly with friends and relatives whom one has not seen in months or even years.

- A lower proportion of interactions based on 'ascriptive' characteristics — such as age, gender, race and social class — and an increased proportion based on 'achieved' characteristics adopted through the life course — such as lifestyles, shared norms and voluntary interests.

- Fostering 'cross-cutting' ties that link and integrate social milieus, instead of such groups being isolated and tightly-bounded.

- Increased choices of milieus in which to get involved.

- Reduced sense of palpable group memberships that provide a sense of belonging.

- Reduced identity and pressures of belonging to groups.

- Increased opportunity, contingency, globalization and uncertainty through participation in social networks.

- Increased emphasis on structural position in different networks — such as brokerage ties that connect multiple networks - and decreased emphasis on group membership. Active networking is more important than going along with the group.

Community gets domesticated Place-to-place community links households that are not in the same neighbourhood (Wellman, 1979; 1999a; Wellman and Leighton, 1979). People go from somewhere to somewhere to meet someone, usually inside their homes. Or people telephone somewhere to talk to someone. The household is what is visited, telephoned or emailed. The community ties of married couples often involve both husbands and wives. They see their friends in common, interact with each other's families and get support from in-laws as easily as they get support from their own kin. It is a privatized relationship that does not involve the local area. Few neighbours are known, and those known are rarely known well (Wellman, 1985; Wellman and Wellman, 1992). Physical closeness does not mean social closeness.

Home is now the base for relationships that are more voluntary and selective than the public communities of the past. Only a minority of community ties in the western world

7 Formally, a group is a special type of network: densely-knit (most people are directly connected), tightlybounded (most ties stay within the densely-knit cluster) and multistranded (most ties contain many role relationships). In practice, it is linguistically convenient to contrast groups and networks. 
operate in the public contexts of neighbourhood, formal organizations or work (Putnam, 2000). Community networks now contain high proportions of people who enjoy each other and low proportions of people who are forced to interact with each other because they are juxtaposed in the same neighbourhood, kinship group, organization or workplace. Friends and relatives get together as small sets of singles or couples, but rarely as communal groups. Where once-public communities had been men's worlds, now home-based community networks bring husbands and wives together. Men's community ties are now tucked away in homes just as women's ties have usually been (Wellman, 1992a; 1999a).

In place-to-place communities, married women not only participate in community, they dominate the practice of it. Women have historically been the 'kinkeepers' of western society: mothers and sisters keeping relatives connected for themselves, their husbands and their children. Women are the preeminent suppliers of emotional support in community networks and the major suppliers of domestic services in households (Wellman, 1992b; Wellman and Wellman, 1992). With the privatization and domestication of community, community-keeping has become an extension of kinkeeping, with both linked to domestic management. Husbands and wives no longer have many separate friendships. Men usually stay at home during their leisure time, and the informal ties of their wives form the basis for relations between married couples. Women define the nature of friendship and help maintain many of their husbands' friendships. Women bear more than the 'double-load' of domestic work and paid work. Their 'triple load' now includes community 'net work'.

The privatization and domestication of relationships are concomitant with place-toplace community. The domesticated community ties interact in small groups in private homes rather than in larger groups in public spaces. This has made it more difficult for people to form new community ties with friends of their friends, and it has focused the concerns of relationships on dealing with household problems (Wellman, 1992a). Women's ties, which have dominated place-to-place community networks, provide important support for dealing with domestic work. Community members help with daily hassles and crises; neighbours mind each other's children; sisters and friends provide emotional support for child, husband and care of the elderly. Because women are the community-keepers and are pressed for time caring for homes and doing paid work, men have become even more cut off from male friendship groups (Wellman, 1992a). In placeto-place communities, North American men have rarely used their community ties to accomplish collective projects of work, politics or leisure. Their relationships have largely become sociable ties, either as part of the relationship between two married couples or as disconnected relations with a few male 'buddies'.

The abundance of within-household interaction and the scarcity of neighbourly community means that the search for the right neighbourhood is not necessarily a search for the right set of community members. People want to live in safe areas, with good public schools for children and good medical resources for the elderly (Dear et al., 1996). Paradoxically, because the lack of neighbourhood community does not preserve local safety, living in a low-crime area is especially important if few neighbours know each other. The value of living in the right place may be another sign of individual and household privatization rather than a sign of a premium on neighbourhood community.

Compared with door-to-door community, place-to-place community operates in a contextual vacuum. The most obvious manifestations are automobile travel (especially on expressways), telephones (since party lines became passé before the second world war; see Fischer, 1992) and email. People and places are connected. Yet there is little social or physical intersection with the intervening spaces between households. People often get on an expressway near their home and get off near their friend/kin's home with little sense of what is in-between. Airplane travel is even more context-less, despite occasional gasps as the Rockies are sighted beneath the clouds. 
The domestication of the Internet Despite the heralding of the Internet as the basis for McLuhan's mythical 'global village', many characteristics of the Internet reinforced place-to-place connectivity. Although an Internet account is usually for a person and not for a place, Internet communications are usually sent and received from a fixed place: home or office. The use of always-on, $24 \times 7$ Internet connectivity increases confidence that people will be available to read your messages or agree to an instant chat. Indeed, it may create false expectations that someone is always accessible and always mobilizable. 'The scarce resource is attention not information', points out James Witte (personal communication, 22 February 2000).

People usually have a good idea of the sociophysical places in which the people they know are reading their messages. If you send a message to your mother, you have a high expectancy that your father will also read it.

The Internet both provides a ramp onto the global information highway and strengthens local links within neighbourhoods and households. For all its global access, the Internet reinforces stay-at-homes. 'Glocalization' occurs, both because the Internet makes it easy to contact many neighbours and because fixed, wired Internet connections root users at their home and office desks. It is to the household or workplace that Internet communications come; the Internet café in the mall is only for outsiders. Many emails are local and refer to local arrangements.

Residents of a wired suburb on a high-speed network are more active neighbours than others in the suburb (Hampton and Wellman, 2000; Hampton, 2001). These wired 'Netville' residents know twenty-five neighbours; the unwired know eight. Their ties range farther through the neighbourhood instead of just clustering on the same block. Nor is glocalization only a leisure-hours phenomenon. While email goes to the place where a person $\log$ s in - usually home or office - it is directed to the person and not to the household. Many business emails are local. More than half $(57 \%)$ of all the email messages received by computer-intensive students in my Berkeley graduate course came from within Berkeley, with another 15\% coming from within the Bay area (Wellman, 1999b). The visiting Norwegian students in the course received many long-distance messages, but almost all were from Norway.

The Internet itself is not fully connected: slow access times, poor phonelines, expensive telecommunications charges, government surveillance and limited access to computers hamper connectivity. Only one-third of the sites at the core of the web are interconnected and easily reachable. Twenty-two percent of all websites are so locally isolated that they cannot be reached by or connected to the core group (Bloomberg News, 2000). Even when the Internet connects globally, it often functions lumpily: messages are not dispersed evenly around the world but are disproportionately exchanged with a few geographical areas, certain types of people or people in the same social networks (including 'friends of friends'). Having global access does not mean having global connectivity.

Because using the Internet is so immersive, Netville residents use it heavily at home. Family members help each other to use computers, share online discoveries and replace time spent watching television with net surfing. One household has a Saturday evening ritual of gathering around the computer with the family and a bowl of popcorn. Parents rarely complain that the time their children and spouses spend online takes away from family activities (Hampton and Wellman, 1999; 2000; Wellman and Hampton, 1999; Hampton, 2001).

The Internet increases long-distance involvement as well as local involvement. When Netville residents receive high-speed connections to the Internet, their social contact and supportive exchanges with friends and relatives living more than 50 kilometres away increase substantially. A large survey of visitors to the National Geographic website also shows that Internet use adds on to - rather than detracts from - in-person and telephone contact with friends and relatives, nearby as well as far-away (Wellman et al., 
2001). Indeed, it may provide a vehicle for reversing the post-1960s decline in American social and organizational involvement (Putnam, 2000).

There are multiple reasons for email involvement:

- It is almost as easy to send a message to ten friends as it is to contact one.

- Group aliases allow people to contact a hundred or more friends by typing a single word.

- Email discussion groups and real-time chat groups provide specialized audiences and some respondents — among the hundreds and thousands.

- Many online ties are palpable, supportive relationships. The Internet is useful both for maintaining strong ties of intimacy and weaker ties of acquaintanceship.

- Rather than being exclusively online or in-person, many community ties are complex dances of face-to-face encounters, scheduled meetings, two-person telephone calls, emails to one person or several, and broader online discussions among those sharing interests.

Controlling connections to resources The turn away from door-to-door contact and towards place-to-place contact has been a twofold turn away from both involvement in a single place and a single group. It is conceptually and practically important not to conflate these two turnings. The shift to place-to-place contact enables people to find community while not being bound up in either their physical neighbourhood (place) or their neighbourhood community (group). Yet place-to-place contact means that localities may still be important — unless friends and relatives hide inside their households — but these localities may be far from where we live. It is the intersection of what Manuel Castells (1996) has called the traditional 'space of places' and the developing 'space of flows'.

Based on interhousehold networks, place-to-place connectivity creates a more fluid system for accessing resources — material, cognitive and influential. No more are people identified as members of a single group; they can switch among multiple networks. Switching and manoeuvring among networks, people can use ties to one network to bring resources to another. The very fact of their tie to another network will be a resource, creating the possibility of linkage, trade and cooperation. The Italian-American 'urban villagers' studied by Herbert Gans (1962) could not prevent their door-to-door community from being destroyed by a municipal-developer alliance intent on building new high-rises. Their bounded community had no links to politically powerful coalitions outside their Boston neighbourhood. Not only do people living in insalubrious neighbourhoods suffer, those without networking resources are interpersonally adrift.

As such, place-to-place connectivity has dual imperatives for controlling resources (Tilly, 1973; 2000). On the one hand, the security of the household base and its surroundings are important, and neighbours are scarcely known and not knit into a strong network. This makes a household's local politics one of securing the property and area with guarded gates, getting people as neighbours with the 'right' demographics and lifestyle, and encouraging a strong, responsive police presence. On the other hand, residents want high-speed, unfettered access to the Internet, expressways and airports to facilitate their links with people in other places (Hampton and Wellman, 2000). Their security concerns start turning to anti-virus checkers, spam and obscenity filters, disk backups, and firewall-like protection against hacker intrusion.

Control of resources in such place-to-place systems is a mixture of control of property and control of networking. Knowing how to network (on and offline) becomes a human capital resource, and having a supportive network becomes a social capital resource (Wellman and Wortley, 1990). The cost is the loss of a palpably present and visible local community to provide a strong identity and belonging. The gain is the increased diversity of opportunity, greater scope for individual agency and the freedom from a single group's constrictive control. 


\section{The rise of networked individualism}

\section{Person-to-person}

From place to person When a close New York relative suddenly became hospitalized in February 2000, Beverly Wellman and I wanted to be always 'on call' in case we were needed in-person. Yet we had just flown to visit friends in Los Angeles and were travelling the freeways between places. Moving around with a mobile phone made me almost completely independent of place. It was I-alone that was reachable wherever I was: at a house, hotel, office, freeway or mall. Place did not matter; person did. The person has become the portal.

The development of person-to-person connectivity has been influenced more by innovations in communication than in transportation. When someone calls a telephone wired into the telephone network, the phone rings at the place, no matter which person is being called. Indeed, many place-to-place ties have connected households as much as individuals. By contrast, mobile phones afford a fundamental liberation from place, and they soon will be joined by wireless computers and personalized software. Their use shifts community ties from linking people-in-places to linking people wherever they are. Because the connection is to the person and not to the place, it shifts the dynamics of connectivity from places - typically households or worksites — to individuals. ${ }^{8}$

The shift to a personalized, wireless world affords truly personal communities that supply support, sociability, information and a sense of belonging separately to each individual. It is the individual, and not the household or the group, that is the primary unit of connectivity. Just as $24 \times 7$ Internet computing means the high availability of people in specific places, the proliferation of mobile phones and wireless computing increasingly means the even higher availability of people without regard to place. From the point of view of people using mobile phones, their supportive convoys travel with them ethereally (Katz, 1999; Katz and Aakus, 2001; Ling and Ytrri, 2001). They can link what they are doing at the moment to their far-flung network, just as I saw a young woman at a Rembrandt etching exhibition in Toronto describing her experience to her boyfriend across the continent in British Columbia (18 June 2000).

Although the switch from door-to-door to place-to-place has enabled communities of choice that were less constrained by distance, place-to-place community has preserved some sense of social context. The shift from place-to-place to person-to-person contact reduces this contextual sense. A caller contacting another by mobile phone or the Internet has uncertain knowledge about the whereabouts of that person. Because mobile people frequently shift from one social network to the other at home or in the office, they contact each other in initial ignorance about their social contexts, unless - like the Rembrandtwatcher - they explicitly describe their surroundings (Mäenpäa, 2000; Townsend, 2000). Rather than being embedded in one social network, person-to-person interactors are always switching between networks.

From interhousehold networks to interpersonal networks Even without door-to-door neighbourhood communities, the household and not the individual has been the key interacting unit in place-to-place communities. In-laws are as supportive as own-kin, and wives frequently arrange visits with their husbands' friends and relatives (Wellman, 1999a). The continuing shift in the western world to single-adult households means that married couples are no longer the demographic heartbeat of America.

Where high-speed place-to-place communication supports the dispersal and fragmentation of community, high-speed person-to-person communication goes one step

8 For a discussion of how this affects home-based teleworkers, see Salaff et al. (1998). 
further and supports the dispersal and role-fragmentation of households. Does the switch to person-to-person connectivity mean that even stably-married husbands and wives will be in separate communities? There may be a return to the separate marital lives that Elizabeth Bott documented over a generation ago in England (1957). 'The nuclear family may be on a comeback', a Rogers ATT mobile phone advertisement says on Toronto radio (CFMX, 13 February 2000: 08.13 EST) with no sense of irony. Dad is bowling with the boys, Mom is on the road making presentations, son Dick is at his computer club, and daughter Jane is out of town visiting her biological Dad. Yet they can all stay connected at low cost through flat-rate national mobile-phone calling. Nor does the dispersion have to be far-flung: I know a 'dot.com' couple who communicate extensively by intercom throughout their heavily-wired Toronto mansion.

Reading and responding to the Internet is more personally immersive than watching television or talking on the telephone. To net surf, someone must peer intently into a nearby screen as if praying to a shrine and finger keys as if they were prayer beads. This kinaesthetic focus on the computer, combined with the bulkiness of the screen, draws computer users away from simultaneously having face-to-face contact with proximate others. Family members have to compete for attention, for closer-to-the-eye computer screens afford less scope for joint interaction than television screens. Telephones allow much more body movement and glances at others than does personal computing. I doubt that many spouses tell their mates to leave the room whenever the telephone rings, just as I assume that most spouses refrain from opening each other's snail-mail. Yet some people are miffed when their spouses read their email. They regard their email address and alias as parts of their personal identity - not to be shared lightly and to be protected in divorce settlements (Cohen, 2000). One concern is that the Internet may be so immersive that its siren call turns people towards their screens and away from their husbands, wives and children (Kraut et al., 1998; Nie and Erbring, 2000; Boneva et al., 2001; Nie, 2001).

Mobile-ization Until now, mobile phones have gone further than personal computers in affording person-to-person contact. At its most fully developed, mobile-ization assumes that callers and receivers are always available, no matter where they may be. It suits and reinforces mobile lifestyles and physically dispersed relationships. It affords liberation from both place and group.

When mobile phones remain at home or in the office they are just another form of place-to-place communication. When they travel in handbags, briefcases or belt-clips they instantly afford person-to-person communication. My friend Janet has a single 'prime number' that first tries her wired telephone at home and then tries her mobile phone. Although I never know where I am reaching her when I call, I always know that I am reaching her and not anyone else in her house. I usually ask 'where are you?' at the beginning, so that I can adjust the length, content and intensity of my conversation. The context of place does matter, even in person-to-person communications, for it is an important component of who we are: our focus, activities, friendships, interests, ability to speak freely and the availability of support. Mobile-phone users can choose where they call from, but they have less control over where they receive calls (Mäenpäa, 2000). As Rebecca Adams notes: 'It is pretty hard for people to define someone's identity if they don't even know where they are in physical or social space when they talk to them on a cell phone' (personal email, 10 January 2000). Because mobile phone costs are low in the United States and western Europe, they often take the place of traditional wired telephones.

As mobile phones proliferate, the norms of this inherently person-to-person system foster the intrusion of intensely-involving private behaviour into public space (see also Lofland, 1998). On Toronto's crowded Spadina streetcar in January 2000, Beverly Wellman and I listened to a young woman carry on an intensely romantic mobile phone conversation with her lover. She seemed oblivious to my sitting next to her. Although we 
followed Erving Goffman's rules (1963) for behaviour in public places and gave her civil inattention, her loud and personal talking transgressed the traditional place-based rules of public behaviour. Her intense involvement in her private conversation - and her loud voice intruding on our soft conversation - appropriated public space for her own needs. What if both parties had been seated side-by-side on the streetcar? It still would have been intrusive, but seeing both parties to the interaction would have provided a more appropriate sense of observational completeness. Observing this intense, one-sided conversation was more like observing masturbation than like observing a couple in love.

Such transgressions are increasing and upsetting nearby involuntary listeners (Taylor, 2000: A21). It is not just the loud noise. Listening through earphones to music on tape and disc players is another example of the personalization of public space. The listener is oblivious to passers-by, often walking into them, and unaware (and apparently uncaring) about the unwanted sounds escaping from his/her earphones.

People who withdraw inward in public space are unsettling, their behaviour signalling that their bodies, but not personas, are passing through. While enjoying the beauty atop Milan Cathedral's roof in November 1999, Beverly Wellman and I were startled when a young woman's mobile phone rang. 'Buon Giorno, Giuseppe', she answered with a squeal of delight and proceeded to have an intimate conversation while standing next to us under a statue of the Madonna. Later, walking through La Scala square, we noticed a middle-aged woman dressed in a Gucci suit talking to herself. 'Even the mentally disturbed wear designer outfits in Milan', I muttered. When she came closer, I saw that she was equipped with the latest in communication chic. With a tiny lapel mike pinned to her collar and a small 'ear bud', she was having a mobile conversation as she walked, the guts of her phone hidden in the Gucci. Watching her, we realized that wearable mobile phones can be a primitive version of multimedia, affording the ability of talking simultaneously on the phone and with both hands (see also Guernsey, 2000).

Some commentators have argued that mobile-ized communicators "who get on everyone's nerves [are] coming from a sense that no one else matters. They're totally selfabsorbed, and they seem to think that the impact of their actions on other people are absolutely inconsequential'. ${ }^{9}$ This is partially untrue: mobile-phone users are communicating, but their communication is often disassociated with the physical place which they are in. They ignore the public aspects of their behaviour. Their failure to relate simultaneously to both cyberplace and physical place is what bothers others. Their awareness and behaviour is totally in private cyberspace even though their bodies are in public space.

Were the women on the Toronto streetcar and atop the Milan Cathedral finding the community in wireless space that they would if they were talking face-to-face? Despite the women's manifest mobile-pleasure, it is likely that they and their lovers would be happier in person, using the senses of sight, sound, touch, smell and mutual cognition. I doubt that there will be androids or avatars up to the task in this century. But love is an extreme case. The more general question is: can people emotionally and cognitively experience relationships through computerized communication systems in the same ways that they experience face-to-face relationships?

Computerization My immigrant grandmother in the Bronx used to shout into the telephone for fear that she would not be heard 45 kilometres away in Brooklyn. A generation later, my Bronxite mother routinely conversed for hours on the telephone with her Brooklyn sister. My generation thinks little of emailing and phoning across the continent. Our home broadband computer connection to the network remains live all day so we can share bright ideas with friends. (Such are the joys of flat-fee monthly rates.) My

9 Thomas White, professor of business ethics at Loyola Marymount University (LA), as quoted by Sharkey (2000). 
twelve-year old niece, Sabrina, comes home from school and immediately checks her 'buddy list' to see which of the friends she has just seen are available online for instant messaging. Yet analysts still privilege email as an exotic communication medium and wonder if it will be a good enough medium to sustain community (Putnam, 2000).

If computer networks transmit information at the speed of light, just as radio/TV broadcasts and telephone networks have done for generations, has computerization enhanced community? First, digital computer networks convey more information per second than analogue telephone networks. Second, computer networks combine the potentially wide reach of broadcast networks with the personalized communication of telephone networks. I first floated an early version of this article on the email discussion list of the American Sociological Association's Community and Urban Sociology section: 300 reasonably-informed persons who knew me as the section's verbose chair. Many responded to the group; some responded to me personally. I next tried a draft of this article on my personal email list of ' 80 Best Friends': people socially close enough to give me a friendly critique. Third, the later version you are reading is a further revised version of one that has been publicly available online for a year. These varied types of communication suggested that email supports: (1) within-network broadcasts; (2) personal communications between one or multiple friends; and (3) public-address systems to strangers. ${ }^{10}$

Because Internet accounts are person-based and not place-based, they are already way-stations on the move to person-to-person community. As high-bandwidth wireless computing becomes prevalent, communicating computers will break their tethers and become placeless. There are already leading-edge indicators of this trend. Internet cafés in malls or main streets allow travellers to keep connected, road warriors use global phone/Internet access networks to connect from hotels or businesses they are visiting, mobile phones are developing Internet capability, and a well-located few have wireless modems on their laptop computers. I know a computer consultant in Silicon Valley who uses a wireless modem to check her email at $8 \mathrm{a} . \mathrm{m}$. while she watches her young daughter play in the schoolyard. As she sips her cappuccino, she is a multitasking harbinger of the convergent integration of a mobile phone's ubiquitous, portable connectivity with the multifunctional power of a personal computer. As satellite links develop and technical standards for wireless communications evolve globally, the same wireless phonecomputer will be able to reach the Internet as easily in Bora Bora as in Silicon Valley.

As community moves out of the household and onto the mobile phone and the modem, there is scope for yet another renegotiation of marital relations. Women have set the rules of the community game in place-to-place relationships and borne the burden of community keeping. If person-to-person community means that it is every person for him/ herself, then we might expect to see a gendered re-segregation of community (as in Elizabeth Bott's England (1957) with the possibility that men's communities will be smaller than networking-savvy women (Wright, 1989; Moore, 1990; Wellman, 1992a; Bruckner and Knaup, 1993).

Is community viable online? As computing power is increasingly used to prioritize and enhance interactions, the power of such person-to-person communication systems is poised to increase, for better or worse. Can true community be found online - in whole or in part - as well as in homes, on the phone, in the mall or on street corners?

10 The process gave me more, better and varied feedback than I had previously experienced when I had shown papers to a few face-to-face colleagues or circulated drafts by snail (postal) mail. I did notice that some online readers responded to me privately instead of to the group. Perhaps they were reticent about being critical in public. I also found that the comments kept on coming and coming, evoking revisions that stretched the forbearance of the IJURR's editors. In some ways it would be nice if online articles could be left open-ended, to be revised when new thoughts and findings occur. However, scholars might never get closure and liberation to move on to the next thing. 
When I circulated a draft of my argument online, political scientist Robert Putnam responded:

I think you're a wild-eyed optimist to think that 'person-to-person' networks are 'just as good as, if not better than' old-fashioned door-to-door (or rather faces-to-faces) networks. But regardless of the differences between us in temperament, you surely cannot think that the two sorts of networks are 'essentially identical' (personal email, 10 January 2000).

Abundant questions arise:

1 Are community ties - and community networks - viable online? Research shows that people interact happily and fruitfully online (for the most part) and in ways similar to face-to-face contact (Wellman and Gulia, 1999).

2 Is the online-offline dichotomy overdone? Many relationships do not exist only online but use online contact to fill the gaps between in-person meetings. Computermediated communication supplements, arranges and amplifies in-person and telephone communications rather than replacing them (Anderson and Tracey, 2001; Howard et al., 2001; Katz et al., 2001; Wellman et al., 2001).

3 Are good online relationships equivalent to good face-to-face relationships where people can see, hear, smell and touch someone, usually in a social context? Probably not, but the question may have a utopian assumption that if people were not online they would be engaged in stimulating community, household or personal activities. Online relationships may be filling empty spots in people's lives now that they can no longer wander to the local pub or café to take up with their community members. Participating in online community probably substitutes for television watching more than for anything else (Nie and Erbring, 2000). As the networked individual substitutes for the lonely crowd, online relationships may be increasing the frequency and intensity of community ties, although at the potential cost of strained household ties. Yet the studies that focus on this look principally at 'newbies' (Kraut et al., 1998; Nie and Erbring, 2000); by contrast, Unix users - veteran Interneters flourish online (Chmielewski and Wellman, 1999).

4 Will the use of computer-mediated communication become more transparent as people become more experienced with it and as such communication develops more verisimilitude through the use of video etc.? Is the comparison with face-to-face relationships always a rigged game in which online relationships can never be quite equal? Would we be wiser to wonder if online interaction will develop its own strengths and create its own norms and dynamics? There are already unique email dynamics in community-building: the folding-in of two disconnected friends into the same conversation, asking personal messages of posters to online discussion groups, developing personal relationships in these groups, typographical conventions of embedding interleaved responses inside original messages, and responding to messages at the top of the message exchange rather than on the bottom (Baron, 2000). 'Email may be richer than face-to-face among people who are distributed, or even between those who are nominally co-located, but on different schedules' (Caroline Haythornthwaite, post to the SocNet discussion list, 14 January 2001). Online communication also extends the reach of networks, allowing more ties to be maintained and fostering specialized relationships in networks. People are increasingly known and related to only in terms of particular aspects of their persona: role-to-role instead of person-to-person, much less person-in-group.

5 Even if not perfect, can online relationships be good enough? Can people emotionally and cognitively respond to online relationships in the same way they respond to face-to-face relationships? One crucial difference between personal relationships and more specialized role relationships is the richness of their history (Banse, 1999). Morever, online communication currently provides a thinner, 
narrower bandwidth of information as compared with in-person and even phone-tophone contact. Yet connecting online does have unique advantages. With respect to history, tracing memory in ageing online archives may be easier. I currently use an online personal directory that primes my interactions with the names of people's spouses, children and mutual friends. In the future, it should be able to provide the titles, abstracts and text of the articles that people have written, as well as reveal their social networks (Contractor et al., 1998; Nardi and Whittaker, 2000).

6 Are relationships based on online communication as authentic and reliable as those in which online communication is only one form of interacting? Although many scholars and the mass media have been fascinated with seemingly-exotic online-only 'virtual communities', it is clear that most people communicate with their friends, relatives, neighbours and workmates by any means available and necessary, online and offline. The stronger the tie, the more media used (Haythornthwaite and Wellman, 1998; 2001; Hampton and Wellman, 1999; 2001; Haythornthwaite, 2000; Koku et al., 2001; Wellman et al., 2001).

7 Will the Internet promote two-person interactions at the expense of interactions happening in group or social network contexts? On the one hand, it is easy to include others in a computer-mediated conversation: just send a message to multiple others, or forward an already-received message. On the other hand, these are always deliberate choices. My niece Sabrina prefers to carry on four separate Instant Messaging duets than to engage in a single five-way conversation. She creates more work for herself but is able to tailor her conversations autonomously. By contrast, people often interact in-person in the presence of others, by happenstance as well as deliberately. This allows the interaction to be observed and affords opportunities for others to join in, even if not invited.

8 As community increasingly becomes person-to-person (and not door-to-door or even place-to-place), will people continue to feel responsible for their strong relationships but not for the many acquaintances and strangers with whom they rub shoulders but are not connected? Private contact with familiar friends and relatives is replacing public gregariousness so that people pass each other unsmiling on streets and highways. Such privatization may be responsible for the lack of informal help given to strangers who are in trouble in public spaces (Latané and Darley, 1976). It may also explain the paradox of well-connected people feeling lonely because of the lack of physically-present community members.

9 To maintain anonymity and freedom of choice, will many people not want to be always - or often - connected? Agency is a need as well as an analytic category. Just as computerized tools for finding others are developing, so are tools that block being found: spam-filters for unwanted email, cookie cutters to avoid being tracked on the web, multiple email accounts for different personas, and secretarial buffers human and cyber. Just as cities have experimented with car-less Sundays, people wanting 'personal space' may refuse to plug into the Internet on nights and weekends. Some already use anonymizers to hide their use of the web and email (Graven, 2001). Science-fiction author William Gibson (the inventor of the term 'cyberspace') believes that in the near future 'people will pay money for something that will make them believe for a while that they are not connected' (quoted in Fulford, 2000: B2).

10 Does the shift to person-to-person networked connectivity mean that people can become more footloose, living almost anywhere as more communication becomes personal and not based on place? For the developed world: yes, no and no. Yes, because many people for short periods can communicate effectively with the Internet, supplemented by the telephone (for nuanced, real-time conversations) and courier services (for the delivery of goods - documents now travel as attachments). No, because the narrower range of Internet communication makes face-to-face contact imperative for maintaining strong ties. No, because it is impossible to duplicate 
elsewhere the complex interplay of urban information, skills, goods, services and networks. Although Jane Jacobs (1961) pointed this out in antediluvian pre-Internet, pre-FedEx times, the joy and usefulness of face-to-face contact is still why Silicon Valley has such a high concentration of technology firms. 'We've shifted from a company-centric economy to a people-driven one' (Richard Florida, quoted in Breen, 2001). Physical place matters, even for cyberspace workers, with people switching firms more often than localities. Travel time also matters, for until the twenty-third century's invention of matter transmission, only bits — and not atoms — can flow through cyberspace.

11 Will less-developed countries suffer a digital divide, and not experience the proliferation of computerized communication networks? Low levels of communication and electrical infrastructure, marked geographical variations in what infrastructure does exist and uneven distributions of wealth mean that any kind of telephone connection is currently rare in large areas of the impoverished 'fourth world'. Four out of five people in the world do not have access to a wired phone; nine out of ten do not have access to a wireless device (Khanna, 2001). Telephone density is less than two lines per 1,000 persons in Africa and 48 per 1,000 in Asia as compared to 520 per 1,000 in high-income countries (Marcelle, 1998; Darkwa and Mazibuko, 2000). These 'switched-off region[s] of the world' are in a state of 'technological apartheid at the dawn of the Information Age' (Castells, 1998: 93-4).

The good news is that the cost of computing is becoming so low that in the developed world the digital social class divide should get smaller just as the digital gender gap has. Even in the less-developed world the growth of wireless computing has made affluent residents less dependent on the national communications infrastructure. The bad news is that schools do not formally teach networking skills. Fortunately, poorer groups in society have always networked heavily for the want of other resources. The problem will be to move from local networking and migrant networking to cyber-networking (Lomnitz, 1977; Roberts, 1978, Espinoza, 1999). It may be then that network capital may provide a partial way of coping with a lack of other forms of capital.

The less-developed world will add elements of person-to-person and role-to-role community to existing door-to-door, place-to-place communities. Transportation of people will generally be door-to-door, with intermittent place-to-place relationships. Communication beyond walking distance will become easier and cheaper as the lower infrastructure costs of mobile phones (and convergent wireless computing) facilitates contact of rural-urban and international migrants, specialized communities, and information about global markets for products.

In areas with little wiring and low telephone density communication will forego wired systems and go straight to mobile-ization. It is cheaper in such situations to erect wireless towers (and perhaps satellite ground stations) than it is to string a wired network. In outlying areas mobile phones will often connect places, not persons: just as in rural America in the early twentieth century the general store was where people would go to use the phone (Fischer, 1992). Over time, personal mobile phones and wireless Internet devices should proliferate for the affluent and for travelling workers (see also Meier, 1962; Castells, 1998; Jhunjhunwala, 2000).

\section{Role-to-role}

Specialized relationships Many interpersonal ties are based only on the specialized roles that people play — not the whole persons. These relationships are between fragments of selves, rather than between whole selves. Such role-to-role relationships have already become abundant in place-to-place community. Most ties are specialized, with different community members supplying emotional support, information, material aid, social 
identity and a sense of belonging (Wellman and Wortley, 1990; see also Fischer, 1982). People must maintain differentiated portfolios of ties to obtain a variety of needed and wanted resources. They cannot assume that all community members will provide all kinds of help because person-to-person connectivity moves responsibility for well-being from the household and network to the two-person dyad.

People often prefer some relationships to be specialized. For example, many collaborating scholars prefer the autonomy of emailing others at a distance to the more compelling, less specialized, face-to-face relationships. They attempt to balance a desire to function according to their own independent rhythms and a desire to obtain the intellectual, material and social rewards of membership in scholarly communities (Koku et al., 2001). For example, among theoretical physicists, shifting from face-to-face contact to disembodied email contact is a possible means of obtaining autonomy: isolation is achieved without effort. These scholars can interact role-to-role without being constrained to deal with the whole person (Merz, 1998).

If role-to-role connectivity becomes even more specialized, who, besides spouses, will worry about the whole person? Specialization means that the emotional supporters will not have to worry about material need, and perhaps will not even know about it. This will lead to lessened loads and pleasures of caring.

What if computerized communication systems afforded greater personalization and specialization by role? Sophisticated telephone and computer response systems may have intelligent agents providing different sorts of responses to different sorts of callers: spouses would hear a different message from that of friends, telemarketers or lovers. What if each person were reading a different version of this article, because I have used personal information to tailor the message that I most want you to receive? ${ }^{11}$ Perhaps the emphases would be different; perhaps the content would change. I might leave out the jokes if high-status people logged on; I might use an appropriate personal example for close friends. If I knew you well enough, I might even use an appropriate personal example from your life. If I did not know you, my software might use heuristic rules to construct an appropriate version tailored to online information about your demographic profile, Internet-surfing tastes, or the friends we have in common. This would be computer-supported communication that was not only person-to-person but personalized role-to-role.

Specialized communities Role-to-role community networks consist of either like-minded people — such as BMW 2002 fanciers — or of people with complementary roles such as violinists and cellists, sadists and masochists. While such communities are abundant now, they are flourishing on the Internet and will become even more abundant as the Internet's capabilities develop. People participate in many ways. They often subscribe to multiple discussion lists and newsgroups, letting others organize the membership and course of the communities. Discussion lists and newsgroups provide permeable, shifting sets of participants, with more intense relationships continued by private email. They can more actively send out messages to personal lists of their own making, perhaps keeping different lists for different kinds of conversations. They can vary in their involvements in different communities, participating actively in some, occasionally in others, and being silent 'lurkers' in still others. The relaxation of constraints on the size and proximity of one's 'communication audience' on the Internet can increase the diversity of people encountered. At some undetermined size, an online community becomes an unstructured crowd.

The Internet affords the development of new connections and the acquisition of new information. Using email lists and newsgroups to ask distant acquaintances and strangers for information and advice is easy. Information may come unsolicited through

11 www.doubleclick.com already does this for web ads (Furger, 2000). 
distribution lists, chat groups, newsgroups, pointers by friends to interesting websites and forwarded messages from friends who 'thought you might like to know about this'. Friends forward communications to third parties and, in so doing, they provide indirect contact between previously-disconnected people who can then make direct contact. When one's strong ties are unable to provide information, one is likely to find it from weak ties. Because people with strong ties are more likely to be socially similar and to know the same persons, they are more likely to possess the same information. By contrast, new information is more apt to come through weaker ties better connected with other, more diverse social circles.

The Internet's very lack of social richness can foster contact with more diverse others. The lack of social and physical cues online makes it difficult to find out if another online community member has similar social characteristics or attractive physical characteristics. Asynchronous communication gives participants more control over the timing and content of their self-disclosures (Walther, 1995). This allows role-to-role relationships to develop from shared interests rather than be stunted at the outset by differences in social status. For example, geographically and socially isolated Muslim women in North America find sociability, support and a sense of belonging in an online discussion group (Bastani, 2000). This focus on shared interests rather than on similar characteristics can be empowering for members of lower-status and disenfranchised groups.

The proliferation of computer-supported specialized ties provide a basis for interestbased structures that provide support, partial solidarity and vehicles for aggregating and articulating interests. This would be an Internet-cum-Tocquevillean substitute for the decline of organized groups that Robert Putnam (2000) has identified as a key problem in America. Even in the pre-Internet France of the early 1990s, friendship and intimacy differentially linked occupational groups. Sales workers and executives were rarely connected, but clerks and blue-collar workers were (Ferrand et al., 1999).

Such specialized communities, based on shared interests, can foster cognitive homogeneity. Despite the Internet's potential to connect diverse cultures and ideas, people are drawn to online communities that link them with others sharing common interests or concerns. They may be more diversified than 'real-life' community in their gender, ethnicity and socioeconomic status, but they still communicate about only a limited set of topics and ideas.

Where person-to-person community is individualizing, role-to-role community deconstructs a holistic individual identity. A person becomes only the sum of her roles, and there is the danger of alienation. The compartmentalization of personal life - within the household and within the community - may create an insecure milieu where no one fully knows anyone (Detelina Radoeva, personal email, 12 January 2000).

\section{Is there a place for physical space in cyberspace?}

The continuing place of space in a world permeated with cyberspace

The 2001 movie (Kubrick, 1968) opens with primitive hominoids gazing at a mysterious, alien monolith. The dramatic structure of its moon-based section is based on scientists travelling across the moon to confer with each other in person and to see the monolith first hand. The conclusion sees an astronaut descending through the cosmos to have firsthand contact with the aliens who created the monolith. At all times, people travel through space to experience the monolith first-hand. Computer mediated communication is an adjunct.

There are movies, and there is reality. To be sure, Kubrick had his movie-making needs to get people in close juxtaposition with each other, and the 1960s' science in 2001 is often wrong in its predictive accuracy. Yet he was expressing a deeper truth: in-person 
contact is still — and will continue to be - the preferred means of communication to the extent feasible. Unless we come to an Asimovian (Asimov, 1957) science-fiction situation of individuals isolated in their homes/ateliers and served only by computers, all but hermits will share tangible, intimate, domestic experiences in a most physical way. 'Our barber and our babysitter will continue to come from places not far away' (Andrew Odlyzko, personal communication, 28 February 2000). 'The kind of jobs, the quality of the water and air, and how [physically] segregated populations are, have almost as much to do with the quality of people's lives as the members of their personal networks and how they are connected to one another' (Beck, 2000).

Atoms - things — as well as bits - computer-mediated communication connect us. Spaces continue to be places, where in-person meetings or passive observations provide a tangible sense of personal identity, a feeling of community, readily-available support in the form of goods and services, and a literally concrete sense of the past and a future (Casey, 1997; Orum and Chen, 2002). Physical space continues to contain and shape interactions, providing opportunities and constraints.

Physical place is thriving. Business air travel for in-person meetings continues to grow (Odlyzko, 1997). People continue to travel profusely by car to get together for work or pleasure. Even the most portable and personal wearable computers will have parts that break or are ergonomically intrusive (Odlyzko, 1999). FedEx and UPS have become the logistic keys to cyber-commerce, delivering the things that people have ordered online; business-to-business e-networks depend on trucks to deliver the goods. Online communications has not diminished the lure of place: Canadians drove more than 300,000 million kilometres in 2000, 280,000 million of which were in cars and light trucks (National Post, 2001), an average of 11,000 kilometres per person (20,000 per household).

Cyberspace fights against physical space less than it complements it. Cyberspace is the medium by which people arrange things and fill in the gaps between meetings. Cyberspace also presents options: people will vigorously communicate with who they want to online in preference to dealing with irrelevant neighbours.

\section{The impact of cyberspace on community}

Although physical place continues to be important, cyberspace has become cyberplace, affecting the ways in which people find and maintain community:

- In the short term, it has made the household more important as a base from which to operate one's computer-supported social network. This can lead to a rise in 'neighbouring', as home-based people take more interest in their immediate surroundings and use the Internet to contact neighbours without physical intrusion and to arrange visits (Hampton and Wellman, 1999).

- Jointly with the mobile phone, it is emphasizing the ascendancy of person-to-person community, contributing (along with other factors) to the de-emphasis of domestic relations.

- It has emphasized individual autonomy and agency. Each person is the operator of his/her personal community network (see also Wellman, 1999a).

- It has afforded greater involvement in communities of shared interest. Such communities have probably become more spatially dispersed.

- It has afforded greater connectivity between communities. The ease of communication to a large number of people facilitates ties that cut across group boundaries.

- Online relationships and online communities have developed their own strength and dynamics. Participants in online groups have strong interpersonal feelings of belonging, being wanted, obtaining important resources and having a shared identity. They are truly in cyberplaces, and not just cyberspaces (Rheingold, 1993; 2000; Wellman and Gulia, 1999). 
- Often, the cyberspace-physical space comparison is a false dichotomy. Many ties operate in both cyberspace and physical space, using whatever means of communication is convenient and appropriate at the moment.

- It has increased the importance of network capital in the fund of desirable resources, along with financial capital, human capital and cultural capital. Such network capital is variegated. It consists of knowing how to maintain a networked computer, search for information on the Internet and use the knowledge gained, create and sustain online relationships and use these relationships to obtain needed resources, including indirect links to friends of friends.

Myopically fixating on the rapidly-developing Internet, hypesters, pundits and wired scholars have all wrongly proclaimed it to be a place apart. Yet systematic research shows that physical space and cyberspace interpenetrate as people actively surf their networks online and offline.

This is a time for individuals and their networks, not for groups. The all-embracing collectivity (Parsons, 1951; Braga and Menosky, 1999) has become a fragmented, personalized network. Autonomy, opportunity and uncertainty rule today's community game. 'Each person sups from many tables, but experiences only a single banquet of life' (Rees-Nishio, 2001).

Barry Wellman (wellman@chass.utoronto.ca), Department of Sociology, University of Toronto, Toronto M5S 1A1, Canada.

\section{References}

Alwang, G. (2001) Peer-to-peer for grown-ups. PC Magazine 16 January, 26-8.

Anderson, B. and K. Tracey (2001) Digital living: the impact (or otherwise) of the Internet on everyday life. American Behavioral Scientist 45 (forthcoming).

Asimov, I. (1957) The naked sun. Doubleday, Garden City, NY.

Banse, R. (1999) Automatic evaluation of self and significant others: affective priming in close relationships. Journal of Social and Personal Relationships 16.6, 803-21.

Baron, N. (2000) Alphabet to email: how written English evolved and where it is heading. Routledge, London.

Barthélmy, D. and P. Contamine (1985) [1988 edn.] The use of private space. In G. Duby (ed.), A history of private life, Belknap Press, Cambridge, MA.

Bastani, S. (2000) Muslim women on-line. Arab World Geographer 3.1, 40-59.

Beck, F. (2000) Re: Communities. Comment on the American Sociological Association Community and Urban Sociology discussion list, 15 January (http://www.commurb.org/ features/futurecommunity.shtml).

Beck, U. (1996) The reinvention of politics: rethinking modernity in the global social order. Polity Press, London.

Berkowitz, S.D. (1982) An introduction to structural analysis: the network approach to social research. Butterworth, Toronto.

Bloomberg News (2000) Internet not as connected as thought. Utah Online [Salt Lake City Tribune] 12 May (http://www.sltrib.com/05122000/business/48507.htm).

Bodemann, Y.M. (1988) Relations of production and class rule: the hidden basis of patronclientage. In B. Wellman and S.D. Berkowitz (eds.), Social structures: a network approach, Cambridge University Press, Cambridge.

Boneva, B., R. Kraut, S. Kiesler and D. Frohlich (2001) Using the Internet for personal relationships: the difference gender makes. American Behavioral Scientist 45 (forthcoming).

Bott, E. (1957) Family and social network. Tavistock, London.

Bradner, E. (2000) Understanding groupware adoption: the social affordances of computermediated communication among distributed groups. Working Paper, Department of Information and Computer Science, University of California, Irvine.

Braga, B. and J. Menosky (1999) Dark frontier: seven of nine goes home. Star Trek Voyager, UPN 
Network, 17 February.

Breen, W. (2001) Where are you on the talent map? Fast Company 42 (http://www.fastcompany.com/online/42/pp_florida.html).

Bruckner, E. and K. Knaup (1993) Women's and men's friendships in comparative perspective. European Sociological Review 9.3, 249-66.

Buderi, R.. (2001) Computing goes everywhere. Technology Review January (http:www.technologyreview.com/magazine/jan01.print_version/buderi).

Buxton, W. (1992) Telepresence: integrating shared task and person spaces. Paper presented at the Graphics Interface Conference, Vancouver, May.

Carlstein, T., D. Parks and N. Thrift (eds.) (1978) Human activity and time geography. John Wiley/ Halsted Press, New York.

Casey, E. (1997) The fate of place. University of California Press, Berkeley.

Castells, M. (1972) The urban question. Edward Arnold, London. (1996) The rise of the network society. Blackwell, Malden, MA. (1998) End of millennium. Blackwell, Malden, MA.

Chmielewski, T. and B. Wellman (1999) Tracking Geekus Unixus: an explorer's report from the National Geographic website. SIGGROUP Bulletin 20 (December), 26-8.

Cohen, J. (2000) Love, honor, cherish. But reveal my password? New York Times 17 February, D1, D9.

Contractor, N.S., D. Zink and M. Chan (1998) IKNOW: A tool to assist and study the creation, maintenance, and dissolution of knowledge networks. Paper presented to the Sunbelt Social Networks Conference, Sitges, Spain, May.

Darkwa, O. and F. Mazibuko (2000) Creating virtual learning communities in Africa: challenges and prospects. First Monday 5.5 (http://firstmonday.org/issues/issue5_5/darkwa/index).

Davis, N.Z. (1983) The return of Martin Guerre. Harvard University Press, Cambridge, MA.

Dear, MJ., H.E. Schockman and G. Hise (eds.) (1996) Rethinking Los Angeles. Sage, Thousand Oaks, CA.

Espinoza, V. (1999) Social networks among the urban poor: inequality and integration in a Latin American city. In B. Wellman (ed.), Networks in the global village, Westview Press, Boulder, $\mathrm{CO}$.

Ferrand, A., L. Mounier and A. Degenne (1999) The diversity of personal networks in France: social stratification and relational structures. In B. Wellman (ed.), Networks in the Global Village, Westview Press, Boulder, CO.

Fischer, C. (1982) To dwell among friends. University of California Press, Berkeley.

- (1992) America calling: a social history of the telephone to 1940. University of California Press, Berkeley.

Foner, L.N. (1997) Yenta: a multi-agent, referral-based matchmaking system. Paper presented at the International Conference on Autonomous Agents ('Agents '97'), Marina del Rey, CA.

Fong, E., B. Wellman, R. Wilkes and M. Kew (2001) Is there a double digital divide? Neighbourhood and individual effects in access to the Internet. Paper presented to the Urban and Regional Development Conference, International Sociological Association, Amsterdam, June.

Forster, E.M. (1909) The machine stops. In E.M. Forster, The eternal moment and other stories, Harcourt, Brace, New York.

Freeman, L. (1992) The sociological concept of group: an empirical test of two models. American Journal of Sociology 98, 152-66.

Fulford, R. (2000) The TEDCity Conference. National Post (Toronto) 10 June, B1-2.

Furger, R. (2000) Who's watching you on the web? PC World March, 33-4.

Gans, H. (1962) The urban villagers. Free Press, New York.

Gaver, W. (1996) Affordances for interaction: the social is material for design. Ecological Psychology 8, 111-29.

Giddens, A. (1991) Modernity and self-identity: self and society in the Late Modern Age. Polity, Cambridge.

Goffman, E. (1963) Behavior in public places. Free Press, New York.

Graven, M. (2001) Leave me alone. PC Magazine 15 January, 151-9.

Guernsey, L. (2000) No, I'm not talking to you. New York Times 8 June, D1, D7.

Hampton, K. (2001) Living the wired life in the wired suburb: Netville, glocalization and civic society. PhD dissertation, Department of Sociology, University of Toronto. 
and B. Wellman (1999) Netville online and offline. American Behavioral Scientist 43.3, 47592.

— and - (2000) Examining community in the digital neighborhood: early results from Canada's wired suburb. In T. Ishida and K. Isbister (eds.), Digital cities, Springer-Verlag, Heidelberg.

- and (2001) Long distance community in the network society: contact and support beyond Netville. American Behavioral Scientist 45 (forthcoming).

Harper, R.H.R., M.G. Lamming and W.M. Newman (1992) Locating systems at work: implications for the development of active badge applications. Interacting with Computers 4.3, 343-63.

Haythornthwaite, C. (2000) Online personal networks: size, composition and media use among distance learners. New Media and Society 2.2, 195-226.

- and B. Wellman (1998) Work, friendship and media use for information exchange in a networked organization. Journal of the American Society for Information Science 49.12, 110114.

— and (eds.) (2001) The Internet in everyday life. Special issue of the American Behavioral Scientist 45 (forthcoming).

Henshall, S. (2000) The COMsumer Manifesto: empowering communities of consumers through the Internet. First Monday 5, May (http://firstmonday.org/issues/issue5_5/henshall.index.html).

Hillery, G. Jr. (1955) Definitions of community: areas of agreement. Rural Sociology 20, 111-22.

Howard, P., L. Rainie and S. Jones (2001) Days and nights on the Internet: the impact of a diffusing technology. American Behavioral Scientist 45 (forthcoming).

Howard, W. (2000) You'll love the on-board DVD player in the back seat of your next BMW. Eventually. Roundel 31, 143-4.

Isaacs, E. (2000) Usage of instant messengers. Paper presented to the Computer Supported Cooperative Work Conference (CSCW2000), Philadelphia, December.

Jacobs, J. (1961) The death and life of great American cities. Random House, New York.

Jhunjhunwala, A. (2000) BytesForAll. Paper presented at the Affordable Telecom \& IT Solutions for Developing Countries Conference, Chennai, India, February-March.

Katz, J. (1999) Connections: social and cultural studies of the telephone in American life. Transaction, New Brunswick, NJ. and M. Aakhus (eds.) (2001) Perpetual contact. Cambridge University Press, Cambridge.

—, R. Rice and T. Aspden (2001) The Internet, 1995-2000. Access, civic involvement, and social interaction. American Behavioral Scientist 45 (forthcoming).

Khanna, P. (2001) Web revolution only just begun. Computer World Canada 12, January, 3.

Kling, R. and S. Iacono (1984) Computing as an occasion for social control. Journal of Social Issues 40.3, 77-96.

Kochen, M. (ed.) (1989) The small world. Ablex, Norwood, NJ.

Koku, E., N. Nazer and B. Wellman (2001) Netting scholars: online and offline. American Behavioral Scientist 45 (forthcoming).

Kraut, R., M. Patterson, V. Lundmark, S. Kiesler, T. Mukopadhyay and W. Scherlis (1998) Internet paradox: a social technology that reduces social involvement and psychological well-being? American Psychologist 53.9, 1017-31.

Kubrick, S. (1968) 2001: A space odyssey. MGM, Los Angeles.

Latané, B. and J. Darley (1976) Help in a crisis: bystander response to an emergency. General Learning Press, Morristown, NJ.

Ling, R. and B. Yttri (2001) Nobody sits at home and waits for the telephone to ring: micro and hyper-coordination through the use of the mobile telephone. In J. Katz and M. Aakhus (eds.), Perpetual Contact, Cambridge University Press, Cambridge (forthcoming).

Lofland, L.H. (1998) The public realm: exploring the city's quintessential social territory. Aldine de Gruyter, New York.

Lomnitz, L.A. (1977) Networks and marginality: life in a Mexican shantytown. Academic Press, New York.

Mäenpäa, P. (2000) Mobile communication as a way of urban life. In A. Warde and J. Gronow (eds.), Ordinary consumption, Harwood, Reading.

Marcelle, G.M. (1998) Strategies for including a gender perspective in African information and communications technologies (ICTs) policy. Paper presented to the ECA International Conference on African Women and Economic Development, Addis Ababa, April.

Markets, A. (2000) Radio active. Wired 6 August, 321-6, 370-2. 
Meier, R. (1962) A communications theory of urban growth. MIT Press, Cambridge, MA.

Merz, M. (1998) 'Nobody can force you when you are across the ocean' — face to face and e-mail exchanges between theoretical physicists. In C. Smith and J, Agar (eds.), Making space for science: territorial themes in the shaping of knowledge, MacMillan, London.

Moore, G. (1990) Structural determinants of men's and women's personal networks. American Sociological Review 55, October, 726-35.

Nardi, B. and S. Whittaker (2000) ContactMap. Working Paper, AT\&T Labs, Florham Park, NJ, November.

National Post (2001) Counting the clicks. National Post (Toronto), 12 January, C2.

Nie, N. (2001) Sociability, interpersonal relations, and the Internet: reconciling conflicting findings. American Behavioral Scientist 45 (forthcoming).

— and L. Erbring (2000) Study offers early look at how Internet is changing daily life. Report, Stanford University, Stanford CA, February (www.stanford.edu/group/siqss/Press_Release/ press_release.html).

Norman, D. (1999) Affordance, conventions, and design. Interactions May-June, 38-44.

Nozawa, S. (1997) Marital relations and personal networks in urban Japan. Working Paper, Department of Sociology, Shizouka University, May.

NTIA (National Telecommunications and Information Administration) (1999) Falling through the Net: defining the digital divide. US Department of Commerce, Washington.

Odlyzko, A. (1997) Electronics and the future of education. Working Paper, AT\&T LabsResearch, 29 March (http://www.research.att.com/ amo/doc/electronics.education.txt).

- (1999) The visible problems of the invisible computer: a skeptical look at information appliances. First Monday 4.9 (http://firstmonday.org/issues/issue4_9/index.html).

Ogburn, W.F. (1950) Social evolution reconsidered. In F.O. William (ed.), Social Change, Viking, New York.

OnSat.net Canada (2000) OnSat delivers first equipment to Honduras. Press Release, 6 September, Calgary.

Orum, A. and X. Chen (2002) Urban places. Blackwell, Malden, MA.

Otani, S. (1999) Personal community networks in contemporary Japan. In B. Wellman (ed.), Networks in the global village, Westview Press, Boulder, CO.

Parsons, T. (1943) The kinship system of the contemporary United States. American Anthropologist 45 (January), 22-38.

- (ed.) (1951) The social system. Free Press, Glencoe, IL.

Paullin, C.O. (1932) Atlas of the historical geography of the United States. Carnegie Institution, Washington.

PC Magazine (2000) Unwired to the Web. PC Magazine 23 June, 85.

Putnam, R. (2000) Bowling alone. Simon \& Schuster, New York.

Randall, N. (2001) Stay in touch. PC Magazine 16 January, 101-4.

Reddick, A., C. Boucher and M. Groseilliers (2000) The dual digital divide: the information highway in Canada. Public Interest Advocacy Centre, Ottawa.

Rees-Nishio, M. (2001) Memorial service for Harry K. Nishio. University of Toronto, 15 January.

Rheingold, H. (1993) The virtual community: homesteading on the electronic frontier. AddisonWesley, Reading, MA.

- (2000 edn.) The virtual community. MIT Press, Cambridge, MA.

Ripley, S. (2001) Mobility rules. PC Magazine 16 January, 72.

Risman, B., D. Tomaskovic-Devey and M. Dimes (eds.) (2000) Utopian visions: engaged sociologies for the twenty-first century. Contemporary Sociology 29.1, 1-94.

Roberts, B. (1978) Cities of peasants. Edward Arnold, London.

Salaff, J., B. Wellman and D. Dimitrova (1998) There is a time and place for teleworking. In R. Suomi, P. Jackson, L. Hollmén and M. Aspnäs (eds.), Teleworking environments: proceedings of the Third International Workshop on Telework, 1-4 September, General Publication No. 8, Turku Center for Computer Science, Turku, Finland.

Schiesel, S. (2000) Zagat survey gets investment for expansion. New York Times on the Web 14 February (http://www.nytimes.com/library/dining/021400zagat.html).

Shapiro, S. (1998) Places and spaces: the historical interaction of technology, home, and privacy. The Information Society 14, 275-84.

Sharkey, J. (2000) Moves to restrict cellphones reflect a growing reaction against a vocal minority of users. New York Times 21 June, C10. 
Smith, T. (1999) The emerging $21^{\text {st }}$ century American family. Report to National Opinion Research Center, Chicago.

Taylor, S.W. (2000) Wireless and witless. New York Times 5 July, A21.

Thébert, Y. (1985) [1987 edn.] Private life and domestic architecture in Roman Africa. In Paul Veyne (ed.), A history of private life, Belknap Press, Cambridge, MA.

Tilly, C. (1973) Do communities act? Sociological Inquiry 43, 209-40.

- (2000) Spaces of contention. Mobilization 5, 135-60.

Townsend, A. (2000) Life in the real-time city: mobile telephones and urban metabolism. Journal of Urban Technology 7.2, 85-104.

Walther, J.B. (1995) Relational aspects of computer-mediated communication: experimental observations over time. Organization Science 6.2, 186-203.

Ward, P. (1999) A history of domestic space: privacy and the Canadian home. UBC Press, Vancouver.

Weaver, M.A. (2000) Democracy by decree: can one man propel a country into the future? New Yorker 20 November, 54-61.

Weiser, M. (1993) Some computer science issues in ubiquitous computing. Communications of the ACM July, 75-85.

Wellman, B. (1979) The community question. American Journal of Sociology 84, 1201-31.

- (1985) Domestic work, paid work and net work. In S. Duck and D. Perlman (eds.), Understanding personal relationships, Sage, London.

- (1988) Structural analysis: from method and metaphor to theory and substance. In B. Wellman and S.D. Berkowitz (eds.), Social structures: a network approach, Cambridge University Press, Cambridge.

(1992a) Men in networks: private communities, domestic friendships. In P. Nardi (ed.), Men's friendships, Sage, Newbury Park, CA.

- (1992b) Which types of ties and networks give what kinds of social support? Advances in Group Processes 9, 207-35.

- (1997) An electronic group is virtually a social network. In S. Kiesler (ed.), Culture of the Internet, Lawrence Erlbaum, Mahwah, NJ.

(1999a) The network community. In B. Wellman (ed.), Networks in the global village, Westview, Boulder, CO.

- (1999b) Ties and bonds. Connections 22.1, 12-18.

(2000a) Changing connectivity: a future history of Y2.03K. Sociological Research Online

4.4, February (http://www.socresonline.org.uk/4/).

(2000b) Must community have a place? An online discussion of the American Sociological

Association's Community and Sociology section, January-February 2000 (http://www.urbsoc.org/communityweb/).

and M. Gulia (1999) Net surfers don't ride alone. In B. Wellman (ed.), Networks in the global village, Westview Press, Boulder, CO.

and K. Hampton (1999) Living networked on and offline. Contemporary Sociology 28.6, 648-54.

and B. Leighton (1979) Networks, neighborhoods and communities. Urban Affairs Quarterly 14, 363-90.

_ and C. Wetherell (1996) Social network analysis of historical communities: some questions from the present to the past. History of the Family 1.1, 97-121.

— and S. Wortley (1990) Different strokes from different folks: community ties and social support. American Journal of Sociology 96, 558-88.

— - A. Quan, J. Witte and K. Hampton (2001) Does the Internet increase, decrease or supplement social capital? American Behavioral Scientist 45 (forthcoming).

Wellman, Beverly and B. Wellman (1992) Domestic affairs and network relations. Journal of Social and Personal Relationships 9, 385-409.

Wenger, E. (1998) Communities of practice: learning, meaning, and identity. Cambridge University Press, Cambridge.

Wolf, E. (1966) Kinship, friendship and patron-client relations. In M. Banton (ed.), The social anthropology of complex societies, Tavistock, London.

Wright, E.O. (1979) Class, crisis and the state. Verso, London.

Wright, P. (1989) Gender differences in adults' same- and cross-gender friendships. In R. Adams and R. Blieszner (eds.), Older adult friendship, Sage, Newbury Park, CA. 